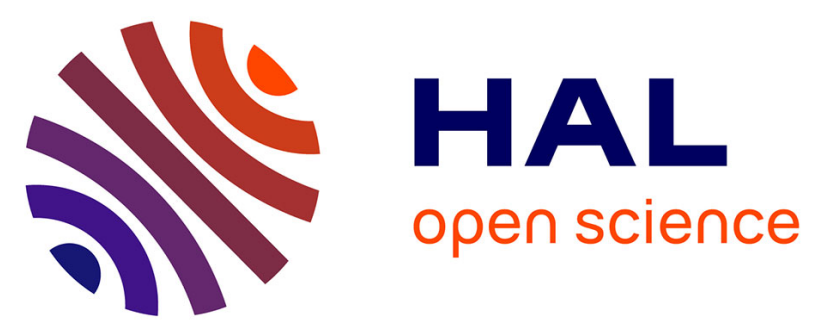

\title{
Perceptions of Diversity Management Practices among First- versus Second-generation Migrants
}

\author{
Sophie Hennekam, Sabine Bacouel-Jentjens, Inju Yang
}

\section{To cite this version:}

Sophie Hennekam, Sabine Bacouel-Jentjens, Inju Yang. Perceptions of Diversity Management Practices among First- versus Second-generation Migrants. Work, Employment and Society, 2020, 34 (5), pp.844-863. 10.1177/0950017019887335 . hal-03232761

\section{HAL Id: hal-03232761 \\ https://hal.science/hal-03232761}

Submitted on 22 May 2021

HAL is a multi-disciplinary open access archive for the deposit and dissemination of scientific research documents, whether they are published or not. The documents may come from teaching and research institutions in France or abroad, or from public or private research centers.
L'archive ouverte pluridisciplinaire HAL, est destinée au dépôt et à la diffusion de documents scientifiques de niveau recherche, publiés ou non, émanant des établissements d'enseignement et de recherche français ou étrangers, des laboratoires publics ou privés. 
Article title: Perceptions of diversity management practices among first-versus second-generation migrants

Authors and Affiliations : - Dr. Sophie Hennekam $\_$Audencia Business School, Nantes

-Dr Inju Yang, RMIT School of Management, Melbourne

Corresponding author: -Dr Sabine Bacouel-Jentjens, ISC Paris Business School, sabine.bacoueljentjens@iscparis.com 
Article Title: Perceptions of diversity management practices among first- versus secondgeneration migrants

\title{
Authors and affiliations
}

\section{Dr. Sophie Hennekam}

Audencia Business School

IRGO, University of Bordeaux

8 Route de la Jonelière

35 Avenue Abadie

44312 Nantes

33072 Bordeaux

France

France

shennekam@audencia.com

+33(0)613114343

Dr. Sabine Bacouel-Jentjens *)

ISC Paris Business School

22, Bd du Fort de Vaux

75848 Paris Cedex 17

France

sabine.bacouel-jentjens@ iscparis.com

+33(0)140539999

\section{Dr. Inju Yang}

RMIT School of Management

RMIT University

445 Swanston Street

Melbourne, VIC 3001

Australia

inju.yang@rmit.edu.au

*) corresponding author

\begin{abstract}
Drawing on an extended case method approach consisting of observations, analysis of organisational documents and semi-structured in-depth interviews with first- and secondgeneration migrants working in a French car manufacturing company, this article examines how and why diversity management practices are perceived differently by first- versus second-generation migrant workers. Using social identity theory and equity theory as a
\end{abstract}


theoretical framework, it was found that first- and second-generation migrants have different social expectations, which, in turn, influence their self-image, as well as their perception of organisational justice. The interaction between their social identity and their perception of justice affects how they appraise diversity management practices in their organisation. The study extends previous research on migrant workers and diversity management by building a conceptual model that outlines how and why diversity management practices are perceived differently by first- versus second-generation migrants.

Keywords: diversity management, equity theory, extended case method, migrant generations, migrant, perceptions, social identity

\section{Introduction}

An increasing number of organisations worldwide invest in diversity management programmes in order to reap the benefits that these approaches can bring to an organisation when they are managed effectively (Kirton and Greene, 2015). Research has started to examine how employees perceive diversity management practices, defined as the set of formalised practices developed and implemented by organisations to manage diversity effectively among all organisational stakeholders (Yang and Konrad, 2011). Employees' perception of diversity management practices is likely to influence their attitude towards diversity.

Moreover, ethnic diversity management is receiving increasing attention from researchers (self-reference author B, in press). For example, there is evidence that secondgeneration migrants continue to encounter discrimination and have difficulties in the labour market (Midtbøen, 2016). Although differences between first- versus second-generation migrants have been studied from an economic and social perspective (Algan et al., 2010), 
possible differences in their workplace experiences have been relatively understudied (Giuliani et al., 2018). The present study fills this gap in the literature by examining whether diversity management practices are perceived differently by first- versus second-generation migrant workers and, if so, why this is the case. The following research questions were formulated: How are diversity management practices perceived by first- versus secondgeneration migrant workers? If there are any differences, why is this the case?

Drawing on social identity theory and equity theory, this article argues that first- and second-generation migrants have different social expectations, which, in turn, influence their self-image, as well as their perception of justice. The interaction between their social identity and their perception of justice affects the way they perceive the diversity management practices in their organisation.

\section{Diversity management practices}

Diversity management refers to the specific programmes, policies and practices that organisations have developed and implemented to manage a diverse workforce effectively and to promote organisational equality (Nkomo and Hoobler, 2014). We know little about the effects of such practices (Dennissen et al., 2018), such as how they are perceived by disadvantaged groups in the workplace. It seems that diversity management practices remain entrenched in identity-based initiatives aimed at increasing the representation of marginalised groups in organisations (Nkomo and Hoobler, 2014). As a consequence, most research on diversity management practices fails to theorise the heterogeneity within identity categories (Dennissen et al., 2018). Building on this identified gap in the literature, this article compares the perceptions of first- and second-generation migrants of diversity management practices. By doing so, the article belongs to a growing body of critical diversity studies (Zanoni et al., 
2010) that criticise mainstream diversity research for focusing on identity as fixed and failing to examine heterogeneity within identity categories.

\section{Migrant generations and social expectations}

The concept of 'generation' refers to the vertical dimension in kinship structures as a universally relevant social categorisation in cultures and societies. In the context of migration, the notion of 'second generation' applies to the offspring of parents who migrated to the country in which their children were then born and raised (Schneider, 2016). In other words, second-generation migrants are descendants of people (first-generation migrants) who left their country of origin and migrated to another country.

It has been argued that whether someone is a first- or second-generation migrant influences what he or she expects in terms of labour market opportunities. From an economic point of view, first-generation migrants compare their situation to their country of origin (Gong et al., 2011). However, second-generation migrants evaluate their social status and opportunities relative to citizens without a migrant background (Shinnar, 2008).

\section{Social identity theory and equity theory}

Social identity theory and equity theory are helpful in explaining how and why first- and second-generation migrants appraise diversity management practices differently. This article argues that the interaction between individuals' social identity and their perception of justice together influence their appraisal of diversity management practices in their organisation.

Identity provides an answer to the question "who am I?" (Ashforth et al., 2008). The answer to this question is context-dependent, as one's identity is constructed in interaction with other individuals and social structures (Ybema et al., 2009). This co-construction is enacted in the interplay between individuals' self-identity (their own notion of who they are) 
and their social-identity (the notion of that individual in external discourses, institutions and culture) (Watson, 2009). It has been argued that individuals should be able to express their multiple identities at work in order to achieve ethnic equality (Janssens and Zanoni, 2014). Moreover, people differ in the extent to which a particular identity is perceived central to themselves and this has an impact on subsequent perceptions. It has been argued that the extent to which migrant workers refer to themselves as migrants influences their perception of discrimination (Sellers and Shelton, 2003).

Social identity theory posits that an individual has one identity made up of several social identities. Social identity is the individual's self-concept derived from perceived membership of social groups. The central assumption underlying this theory is that while in some situations people think of themselves as individuals who interact with each other on the basis of personal characteristics, there are also settings in which people think of themselves and others in terms of particular group memberships (Leary and Tangney, 2005).

Equity theory relates to perceptions of justice (Adams, 1965). The theory posits that an individual's actions and motivations are guided by justice perceptions and any inequity perceived within the workplace could lead to the creation of tension and dissonance. Equity theory is studied within the context of the relational satisfaction of employees, in which they aspire to maintain a balance between what they give to the organisation and what they receive. Individuals perceive inequity 'if the Outcome/Input ratio is not approximately equal to that of the comparison other' (Hayibor, 2017: 48). As one compares oneself with someone else, it is important to know who this "comparison other" is. This article argues that firstgeneration migrants compare their situation with other migrants in the organisation, as those workers tend to work together in the lower strata of society (Van Laer and Janssens, 2014). However, second-generation migrants might compare themselves with native majority individuals. Having migrant status can have a negative impact on an individual's employment 
opportunities and career progression (Van Laer and Janssens, 2011) and some researchers have found that second-generation migrants might have more negative perceptions of fairness and meritocracy (Wiley et al., 2012). Other research, however, has shown that there is an acculturation of trust among non-Western migrants when migrating to Western Europe and that second-generation migrants tend to adapt more to the level of trust of non-migrants than first-generation migrants (Dinesen and Hooghe, 2010). Research on the potential differences in perceptions of justice among first- and second-generation migrants is, therefore, inconclusive.

Previous research has shown that an individual's perception of justice influences that person's attitudes and behaviours and distinguish between distributive, procedural and interactional justice (Colquitt et al., 2001). Distributive justice refers to an individual's perception of justice regarding the outcomes of the decisions and actions of an organisation. As those judgements and perceptions regarding distributive justice (i.e., the fairness of outcomes) are shaped, individuals also take into consideration the means or processes utilised to arrive at the outcome. The perceived justice of the process being utilised to arrive at the outcome provides the underpinnings of procedural justice (Sweeney and McFarlin, 1997), with unbiased and consistently applied processes being perceived as more favourable (Whisenant et al., 2015). Finally, the perception of being treated with dignity and respect forms the basis of interactional justice (Moorman, 1991). It has been argued that human resource management systems continue to be culturally biased, overvaluing the skills and qualities of non-migrant workers (Janssens and Zanoni, 2014). Indeed, historically, organisations tended to value the skills of power holders and downplay the abilities of individuals in disadvantaged groups (Van Laer and Janssens, 2016). As a consequence, coming from a particular ethnic background is associated with a particular skill level (Janssens and Zanoni, 2014). This structural bias in terms of skills and competencies 
disadvantages migrants in a structural way, which maintains and reinforces inequalities at work (Acker, 2006).

\section{Migrants in the French context}

European countries have experienced migration from other countries for decades. Public interest in migrants has risen with the emergence of the European migration crisis, as large numbers of migrants, mainly from Africa and the Middle East, arrived in Europe. Since 2015, religiously motivated terrorist attacks, in particular in France but also Germany and the UK, committed in part by European-born descendants of non-European migrants, have added to a controversial public debate on migration. In this context, Lacroix (2015) points out that, in France today, the real question is the place of the descendants of migrants, rather than new migrant arrivals. The migration debate is rooted in the country's post-colonial past and in its assimilationist policies (Dennison and Talo, 2017). The idea behind assimilation was that, by adopting French values and culture, citizens from the colonies would be considered French (Lacroix, 2015). Today's far-right populist discourse in France juxtaposes the idea of the "French" as an in-group and migrants and/or their descendants as an out-group, who are considered "unwilling to adapt" and represent a threat to French values and traditions (e.g., France's traditional secularism versus the supposed Islamisation of French society) (Dennison and Talo, 2017).

However, the focus on assimilation does not seem to have prevented widespread employment discrimination or the establishment of ethnically segregated areas in poorer suburbs of France (Algan et al., 2010). Related to employment, equal access to education in France has been deteriorating for the last ten years, according to the Programme for International Student Assessment (PISA) study, which examines the impact of socio- 
economic background on school performance (Organisation for Economic Co-operation and Development, 2013).

As French law prohibits the collection of data on certain demographic characteristics, such as ethnicity, data on the number of workers with French citizenship but with a migrant background are not available. French statistics categorise individuals based on both nationality and place of birth (National Institute of Statistics and Economic Studies [INSEE], 2016a), thus differentiating migrants (first-generation) and descendants of migrants (secondgeneration). The migrant population is made up of people now residing in France who were born abroad and were foreign nationals on arrival. It includes, therefore, people who have acquired French nationality since their arrival. A descendant of migrants is a person born and resident in France, having at least one migrant parent. In 2013, migrants represented about 9\% of the population in France, of whom 37\% were European and 44\% African migrants (INSEE, 2016a). Descendants of migrants represent another 10\% of the population (INSEE, 2016b).

In summary, this article examines whether and how diversity management practices are perceived differently by first- versus second-generation migrant workers in France and, if there are any differences, why this is the case. The extended case method approach to answering the research questions, which consisted of observations, analysis of policies, programmes, orientation materials and a review of other organisational documentation and 16 semi-structured in-depth interviews, is explained below. This article posits that an individual's social identity and sense of justice together influence the perceptions among first- and secondgeneration migrants regarding diversity management practices.

\section{Context and method}

This research adopted an extended case method approach (Burawoy, 1998), consisting of observations, analysis of organisational documents and in-depth interviews. A case study is a 
detailed examination of a single situation; in this case, a French car manufacturing company. Multi-systemic analysis of this case was used to extend existing theory with data from the field. The extended case method links individual experiences to the broader social and economic milieu (Burawoy et al., 1991), adding complexity to the findings. In this study, the different sources of the data helped to contextualise the in-depth interviews and observations. The study was conducted in a French car manufacturing company in 2016. The company was chosen because it is known for its commitment towards diversity. The organisation adopted the French Diversity Charter in 2004, consisting of a voluntary moral commitment that encourages organisations to promote and respect workplace diversity by combating discrimination and putting diversity policies in place (Klarsfeld et al., 2012). It should be acknowledged that the automobile industry in France has received a lot of attention from sociologists over the past 50 years (Rot, 2006). However, diversity is not often perceived as an asset in this industry. In her case study of an automobile company in Belgium, Zanoni (2011) showed that the discursive construction of social identities based on gender, age, ethnicity or disability put a negative label on those identities, positioning them as less able, flexible and valuable workers. As such, those discursive constructions of socio-demographic identities operate as proxies for the perceived lower potential of groups, such as migrants, in the workforce.

In the company under study in this article, the workforce comprised $55.7 \%$ blue-collar workers and $5.2 \%$ of the workforce was of foreign nationality. Sixteen face-to-face semistructured in-depth interviews were conducted, which is a relatively small sample but suitable given the methodological approach. The sample consisted of migrant workers, who occupied different functions and various hierarchical positions in the organisation. Nine interviewees were first-generation migrants and seven were second-generation. Their average age was 44.3 years (with a range from 32 to 56 years) and $75 \%$ of the sample was male. Interviewees were 
recruited on a voluntary basis by the organisation and, therefore, a self-selection bias needs to be acknowledged. The demographic characteristics of the sample are provided in Table 1.

$<$ TABLE 1 here>

The interviews lasted around 60 minutes, were conducted in French, audio-recorded and transcribed. Anonymity was guaranteed and the interviewees were told they could stop the interview at any time. Each interview consisted of questions regarding the interviewee's position, his/her personal background, personal experience with diversity, inclusion and discrimination, the organisation's diversity policies and the interviewee's evaluation of them. The interviewees were asked about formalised diversity management practices because, once such practices are formalised and implemented, they are rarely removed (Kalev et al., 2006) and tend to spread across the organisation. As suggested by Kossek and Pichler (2006), we distinguished between three types of diversity management practices: 1. practices that enhance perceptions of justice and inclusion; 2. practices, such as affirmative action, which reduce discrimination; and 3. practices that improve the financial and competitive position of the organisation. An interview guide was used to address interviewees' perception of those types of diversity management practices and other issues brought up by the interviewees were discussed, in line with our semi-structured design.

In addition, the first researcher shadowed some of the employees regularly throughout the eight months of the research project in order to observe patterns in how they interacted with various colleagues during aspects of work directly related to the organisation's diversity management practices. Finally, policies, programmes and orientation materials were analysed and other organisational documentation reviewed. 
The interview data, observations and documentation analysis results were triangulated and integrated. This material was used to gain greater understanding of the context in which the accounts of the interviewees were embedded. This led to deeper understanding and increased the validity of the results.

The analysis was conducted by hand without the use of a software package. Three inter-related steps can be distinguished. The analysis was iterative in nature and the researchers had to go back and forth between the transcripts and coding book in order not to lose sight of the context in which things were said. Figure 1 below shows how the analysis evolved from the first-order themes to the broader categories and dimensions in the third step. It was noticed that first- and second-generation interviewee groups responded in distinct ways: interviewees from both the first- and second-generation groups tended to agree strongly with others from the same generation as themselves, while important differences between the generational groups were identified. Each of the two sub-groups was thus very homogeneous in its accounts, despite differences in ethnic background and other demographic variables. This emerged naturally from the data and was not anticipated. As a consequence, the researchers coded the data again by generational group.

In the second step of the analysis and after coding the data, the researchers focused on the connections between the themes and the identification of higher-order conceptual codes. At this stage, the observational notes as well as organisational documents and artifacts were integrated with the analysis in order to provide a more contextual understanding of the themes. The second-order themes can be found in the second column of Figure 1. In the last step of the analysis, the second-order themes were integrated into aggregated theoretical dimensions, which can be found on the right in Figure 1. Social identity theory and equity theory were used to guide the analysis at this stage. 
$<$ FIGURE 1 here >

\section{Findings}

The data reveal that an individual's perception of diversity management practices is influenced by whether that person is a first- or second-generation migrant worker. More precisely, the migrants' social expectations influenced their social identity and their perceptions of fairness, which is related to their appraisal of diversity management practices in the organisation. This conceptual model is depicted in Figure 2.

$<$ FIGURE 2 here $>$

The conceptual model is explained in more depth below. Quotations are used to illustrate the main points.

\section{Social expectations}

First- and second-generation migrants reported different social expectations, which resulted from whether migration had been a choice and whether they compared themselves with other migrants or non-migrants. While migrating to France had been a voluntary action for the firstgeneration workers, it was a given for the second-generation:

I'm Tunisian and I've chosen to come to France because there is more freedom. I couldn't stay under the former Tunisian regime (first-generation, male, Tunisian). 
I'm born in France, I pay my taxes in France, I contribute to French society. I'm French, I have a French identity card. I've been to school in France, I have the same rights (second-generation, male, Algerian).

First-generation workers were generally content to be in France, as they were satisfied with having work:

I'm from Senegal and I've been very lucky to be hired here with a permanent contract. It has really been a great opportunity for me (first-generation, male, Senegalese).

Second-generation interviewees compared themselves with non-migrant individuals:

I want to be perceived and treated like anyone else. I deserve to be treated in the same way (second-generation, female, Serbian).

Their expectations do not seem to be shared or understood by first-generation migrants:

The new generation is different, they want to be paid well right away, they have very high expectations. They know their rights but not their duties (first-generation, male, Moroccan).

The above social expectations influenced the way migrants perceived themselves and affected their perception of fairness. 


\section{Social identity}

The way migrants defined themselves was affected by their self-image in the organisation. First-generation migrants perceived themselves as foreigners:

We're not French, so it's up to us to adapt and put in some effort (first-generation, male, Tunisian).

I have never felt any difficulties regarding my ethnic minority position (firstgeneration, male, Serbian).

Second-generation migrants perceived themselves as French nationals, without mentioning their migrant status. However, they acknowledged that this perception is not necessarily shared by French workers without migrant heritage:

I expect to be treated like a native French person (second-generation, male, Burkinabé).

When I became supervisor of a unit, people made me feel awkward, although they didn't say anything openly. I told them that I was born in France. Some people do not like this. (second-generation, male, Algerian).

In the eyes of the French people, even if I'm born in France, I'm still being perceived as a foreigner (second-generation, female, Algerian). 
Unsurprisingly, whether the migrants' ethnic background was visible played a role in that migrants with a visible ethnic minority background reported more discrimination and less justice than individuals whose ethnic background was not visible.

\section{Perception of justice}

Individuals' perception of fairness related to whether they were treated as equals or whether their cultural background influenced their opportunities for advancement at work.

A distinction was made between distributive, procedural and interactional justice (Colquitt et al., 2001). The interviewees reflected on the factors that influenced career success, procedural and distributive justice being particularly relevant. Procedural justice reflects the fairness of the processes used to decide who receives career development opportunities and how these are implemented and distributive fairness concerns the outcomes of the decisions and actions of an organisation (Brockner and Greenberg, 1990). Firstgeneration migrant interviewees perceived career development to be based on skills and merit, as related to diversity management practices that enhance perceptions of justice and inclusion (Kossek and Pichler, 2006):

If you have the skills, you can grow in the organisation (first-generation, male, Senegalese).

Whether you're yellow, white, black or whatever, if you deserve to be promoted, they will do so (first-generation, male, Serbian).

In contrast, second-generation migrant interviewees perceived that a migrant background negatively influenced someone's opportunities. When this process of career 
development is non-transparent, perceived as being based on subjective criteria (procedural justice) and leads to outcomes that they consider to be unfair (distributive justice), this leads to perceptions of injustice:

There are not a lot of people from the Magreb region in managerial positions (secondgeneration, female, Algerian).

First-generation migrants also mentioned the availability of training opportunities that could further their career:

I have had training to improve my skills so that I could change function. If one has the skills, one can progress. This is really good (first-generation, male, Cambodian).

In addition, a first-generation team leader pointed out that some workers felt that they were discriminated against, but argued that this perception was unjustified and emphasised that it was a person's skills and competencies that determined career progression:

Selection and promotion are based on one's competencies. It is thanks to their skills that people find themselves in their positions. There are people who feel discriminated against. However, it is often the case that they do not have the competencies needed, although they may think they have them (first-generation, male, Portuguese).

In contrast, second-generation migrants expressed frustration with the lack of career progression and limited opportunities. The second generation was more likely to attribute those negative experiences to societal barriers and systematic rejection. In line with earlier 
research, members of this generation were more pessimistic and disillusioned about the future than the first generation (Wiley et al., 2012). Second-generation migrants referred to distributive justice, reflecting on the fairness of the outcome of organisational policies and practices:

I have seen native French coworkers advance much faster than I did (secondgeneration, male, Martinican).

I've known some excellent colleagues from Morocco and Algeria who should have been promoted. However, they haven't moved up in the hierarchy as a result of their ethnic origin (second-generation, male, Burkinabé).

Moreover, perceptions of prevailing negative stereotypes and discrimination were widespread among second-generation migrants:

Some people do not want to interact with us based on some negative ideas they hold about us (second-generation, male, Martinican).

We see this negative image of African people on TV and generalise this to all Africans. So when they see someone with an African background in the organisation, they already have those negative stereotypical ideas (second-generation, male, Burkinabé).

However, this was less the case among first-generation migrants. They reported positive interactions with coworkers and a good ambiance at work. This relates to 
interactional justice, which is characterised by 'respectful and socially sensitive treatment' (Bies, 2005: 93):

I do not see any discrimination or racism here (first-generation, male, Senegalese).

We work in harmony, we get along, joke around, talk and laugh (first-generation, female, Turkish).

I respect everyone and as such I'm respected by others (first-generation, male, Portuguese).

Social identity and the perception of fairness together led to different perceptions regarding diversity management practices, in which first-generation interviewees had a more positive perception of such practices than second-generation migrants:

Diversity management works well here (first-generation, male, Chinese).

Diversity management doesn't work in practice. It's implicit, but you can feel it (second-generation, male, Algerian).

In summary, first-generation migrants had a positive perception of diversity management practices. They considered themselves lucky, as they compared their situation with either the situation in their countries of origin or with other migrants in France who worked mainly in similar low-skilled occupations. They mentioned diversity management practices that reduce discrimination (Kossek and Pichler, 2006) and did not perceive 
discriminatory practices based on their ethnic background that had hindered their career development or affected their access to training. Rather, they expressed faith in the organisation's competency-based procedures and reported that those diversity management practices enhanced inclusion and justice. However, second-generation migrants' appraisal of diversity management practices was quite different. Second-generation migrants compared themselves with non-migrant workers and were sensitive to and critical of perceived injustices and discrimination. They highlighted tensions in social interaction and felt that they were perceived differently because of their ethnic background.

\section{Discussion}

As diversity management has become a fundamental part of the human resources function in many organisations, it is important to understand how diversity management practices are perceived by the employees the policies are intended to benefit. Diversity management is designed with minorities or disadvantaged groups in mind but sometimes does not differentiate between members of a disadvantaged group. Adding to a stream of critical diversity studies (Zanoni et al., 2010), this article challenges the assumption of homogeneity of identity categories by studying the different appraisals of diversity management practices between first- and second-generation migrants in a French car manufacturing firm.

Drawing on organisational justice theory, it can be seen that the first-generation migrants in this study had a positive appraisal of diversity management practices, as they believed that they were being treated with respect and felt that career progression was based on merit. This is interesting, as previous research has shown that minorities that endorse system-justifying beliefs (the belief that hard work leads to success) may react to diversity initiatives in a similar way to high-status groups (Major et al., 2002). First-generation migrants may judge themselves to be economically successful because they compare 
themselves with people in their country of origin. They may attribute their achievements to personal hard work and effort, which are rewarded by an organisation as part of a competence-based promotion policy. In addition, the first-generation migrants in this study perceived that the company used competencies, but also motivation and loyalty, to determine career progression, which mirrors a "best case" study by Janssens and Zanoni (2014) of a call centre in Belgium. First-generation interviewees felt valued because, from their perspective, the organisation under study refrained from using an ethnocentric approach to whom is considered to be a 'good worker' (MacKenzie and Forde, 2009).

In contrast, it appears that second-generation migrants felt relatively unsuccessful and unrewarded because they compared themselves with non-migrant citizens and attributed their lack of progress to prejudice. The finding that second-generation migrants expressed more experience of discrimination echoes previous studies in Western countries that found that discrimination seems to be a stronger obstacle for second-generation migrants than for first generations of Asian, Latino and other minority groups, hindering their integration and leading to lower psychological well-being (Giuliani et al., 2018). This finding is, however, in contrast with recent research comparing the perception of in-group discrimination among first- and second-generation migrants in 27 European Union member states, which found that second-generation migrants were less likely to perceive discrimination (André and Dronkers, 2017). The finding that the second-generation migrants in the present study perceived more inequality and discrimination might lead to a vicious circle, in which perceived social immobility heightens the centrality of their ethnic identity and hence increases perceived instances of discrimination (Major et al., 2002). Discrimination experiences intensify ethnic identification (Fleischmann et al., 2011) and reduce national (host country) identification (Giuliani et al., 2018). 
Previous research has also found that first- and second-generation migrants differ in their perception of work-related practices and experiences such as discrimination (Liu and Suyemoto, 2016). Other than the findings presented in this paper related to social identity and perceptions of justice, other possible explanations have been put forward. For example, second-generation migrants might have had more time to interact and socialise with the wider society, which has highlighted their ethnic minority identity (Kaduvettoor-Davidson and Inman, 2013). Another explanation lies in their higher linguistic abilities compared with firstgeneration migrants, making them more aware of the subtleties of unfairness and discrimination (Kaduvettoor-Davidson and Inman, 2013), leading to a more negative perception of diversity management practices. In the same line of reasoning, first-generation migrants might have maintained a stronger connection with their country of origin, buffering their exposure to experiences of negative treatment (Kaduvettoor-Davidson and Inman, 2013) and resulting in a more positive perception.

The above findings have implications for practice. Given the variation in perceptions of diversity management depending on migration history, it is important to create an inclusive workplace in which individuals of all backgrounds are fairly treated, valued for who they are and are included in core decision-making (Nishii, 2013). However, the creation of an inclusive climate at work requires more than increasing diverse representation and implementing equitable human resources practices. Rather, it requires a change in interaction patterns (Nishii, 2013). Organisations need, therefore, to create an inclusive climate in which individuals feel they can be themselves. This should increase feelings of authenticity and connectedness or belongingness (Shore et al., 2011).

The findings show that first- and second-generation migrants differed in the way they perceived the role of skills and competencies regarding career development. All the interviewees saw competencies as a core requirement for career advancement but disagreed as 
to whether their skills were recognised at work. A culturally defined perception of which skills are valuable should be challenged and so, therefore, should ideas of who is perceived to be competent (Janssens and Zanoni, 2014). Cultural assumptions about the skills, work ethic or aspirations of migrants need to be challenged by redefining norms and broadening the skills and competencies that are considered valuable for an organisation. This can be done, for example, by creating multi-ethnic teams, making the value of migrant workers obvious to others and challenging the assumption that they are less competent. In addition, diversity networks can offer support and career advice and create connections within and between identity groups (Dennissen et al., 2018), so that the dynamics of oppression and privilege within their institution can be discussed.

Furthermore, the second-generation migrants in this study felt they were perceived differently by French workers without a migrant background, which is in line with previous studies (Van Laer and Janssens, 2011). Individuals seek to maintain their identities, so their expression of who they are should be encouraged, while also allowing for multiple identities. Workers should be perceived as full employees by taking steps to avoid reducing them to a social category to which they are perceived to belong. This can be related to an integration strategy that allows individuals to keep their ethnic identities. By doing so, migrants might perceive less identity threat at work, avoiding negative outcomes for individuals and organisations alike (Van Knippenberg et al., 2004).

Below, the findings related to the three types of diversity practice identified earlier are reflected upon (Kossek and Pichler, 2006): those that enhance perceptions of justice and inclusion, those that reduce discrimination and those that improve the position of the organisation. Interviewees reported both diversity management practices aimed at reducing discrimination and practices aimed at enhancing justice and inclusion, although these were perceived differently by first- and second-generation migrants. Previous research has argued 
that diversity management practices, such as affirmative action, which seek to reduce discrimination can have a stigmatising effect on minority workers. Moreover, research has found that the underlying rationale for diversity plays a role, in that an instrumental perspective on diversity, focusing on achieving business success, is perceived by migrants as less stigmatising (Olsen and Martins, 2012). As a consequence, organisations might want to avoid diversity practices that can have a stigmatising effect on migrant workers (such as affirmative action). Diversity practices that enhance perceptions of justice and inclusion (Kossek and Pichler, 2006), such as the creation of an inclusive climate, diversity training or a mentor programme, might be more effective.

This study also has some theoretical implications. First, it has criticised the essentialist notion of identity categories and added to the theorisation of heterogeneity within identity categories, such as migrant identity (Dennissen et al., 2018), by using social identity theory and equity theory. In line with Schwab et al. (2016), this article shows that integrating multiple theoretical perspectives is helpful in enhancing understanding of issues related to diversity management.

In line with social identity theory, the first-generation migrants in this study perceived themselves as ethnic minorities and compared their situation with that of individuals in their country of origin, whereas second-generation migrants compared themselves with nonmigrant individuals and perceived that they were treated differently, resulting in feelings of injustice. Previous research in France on ethnic minority workers has shown that their ethnic identity usually prevails over their national identity (Sabatier, 2008). Therefore, it has been argued that migrants rarely achieve an integrated or bicultural identity and more frequently adopt a separation strategy, in which they keep their own cultural heritage and do not adopt the dominant culture (Berry and Sabatier, 2010). This article shows that this has implications for the way migrants appraise diversity management practices in their organisation. 
Equity theory deals with perceptions of injustice in an organisation. Perceptions of injustice lead to various psychological, emotional, physiological and behavioural responses, many of which are undesirable from an organisational standpoint. As a consequence, it is important for organisations that their employees perceive the process and outcome of the organisation's actions as fair. Moreover, the findings highlight that individuals are sensitive to the way they are treated, so attention should be paid to issues relating to favouritism, stereotypes and discrimination. The interviewees seemed to be particularly sensitive to procedural and distributive justice, so transparent communication about how promotional decisions are made, how practices are implemented or how someone's value is determined within the organisation is important to avoid perceptions of injustice.

Finally, some limitations should be acknowledged and suggestions for future research can be formulated. First, it is likely that there exist strong differences within this group of migrants, as those with Asian heritage, for example, may differ substantially from those with North African heritage. Second, the findings show that non-visible migrants reported less discrimination and injustice than visible migrants. Being hypervisible, as is the case for some migrants based on their skin colour, has been found to have an impact on an individual's productivity, commitment and sense of belonging at work (Wingfield and Wingfield, 2014). The hypervisibility of some migrants has been found to lead to negative treatment, such as discrimination, as they are perceived as deviant, leading to increased surveillance from others (Settles et al., 2018). This hypervisibility of their ethnic background obscures their personal identities, as they are seen only in terms of their marginalised group membership. It is not, therefore, surprising that migrants that are less visible fare better than migrant workers whose migrant heritage is visible. Therefore, it is suggested that future diversity research looks at the experiences of ethnic groups based, for example, on skin colour, religious beliefs or country of origin. 
Third, while the present research design cannot establish causal relationships, the interviewees explained how their migrant history influenced their social expectations, which, in turn, affected their social identity and perception of justice. The proposed conceptual model could be tested and refined in future quantitative research endeavours.

\section{Conclusion}

Adding to a stream of critical diversity studies that have called for more research on the heterogeneity within identity categories, this study examined how and why diversity management practices are perceived differently by first- and second-generation migrant workers. Drawing on an extended case method approach, consisting of observations, analysis of organisational documents and semi-structured in-depth interviews with migrant workers in a French car manufacturing company, it was found that first- and second-generation migrants have different social expectations, which, in turn, influence their self-image, as well as their perception of organisational justice. The interaction between their social identity and their perception of justice affects the way they appraise diversity management practices in their organisation. The findings show that it is important that migrant workers are perceived as full employees, feel valued for what they do and can express their ethnic identity at work.

\section{References}

Acker JR (2006) Inequality regimes: Gender, class, and race in organizations. Gender and Society 20(4): 441-464.

Adams JS (1965) Inequity in social exchange. In: Berkowitz L (ed) Advances in

Experimental Social Psychology. San Diego CA: Academic Press, 267-299. 
Algan Y, Dustmann C, Glitz A, and Manning A (2010) The economic situation of first and second-generation immigrants in France, Germany, and the United Kingdom. The Economic Journal 120(542): 4-30.

André S, Dronkers J (2017) Perceived in-group discrimination by first and second generation immigrants from different countries of origin in $27 \mathrm{EU}$ member-states. International Sociology 32(1): 105-129.

Ashforth BE, Harrison SH, and Corley KG (2008) Identification in organizations: An examination of four fundamental questions. Journal of Management 34(3): 325-374.

Berry JW, Sabatier C (2010) Acculturation, discrimination, and adaptation among second generation immigrant youth in Montreal and Paris. International Journal of Intercultural Relations 34(3): 191-207.

Bies RJ (2005) Are procedural justice and interactional justice conceptually distinct? In: Greenberg J, Colquitt JA (eds) Handbook of Organizational Justice. Mahwah NJ: Lawrence Erlbaum Associates, 85-112.

Brockner J, Greenberg J (1990) The impact of layoffs on survivors: An organizational justice perspective. In: Carroll JS (ed) Applied Social Psychology and Organizational Settings. Hillsdale NJ: Lawrence Erlbaum Associates, 45-75.

Burawoy M (1998) The extended case method. Sociological Theory 16(1): 1-33.

Burawoy M, Burton A, Ferguson AA, and Fox KJ (1991) Ethnography Unbound: Power and Resistance in the Modern Metropolis. Berkeley CA: University of California Press.

Colquitt JA, Conlon DE, Wesson MJ, Porte C, and Ng KY (2001) Justice at the millennium: A metaanalytic review of 25 years of organizational justice research. Journal of Applied Psychology 86(3): 425-445. 
Dennison J, Talo T (2017) Explaining attitudes to immigration in France. EUI Working Paper RSCAS 2017/25. European University Institute Robert Schuman, Centre for Advanced Studies, Migration Policy Centre.

Dennissen M, Benschop Y, and van den Brink M (2018) Rethinking diversity management: An intersectional analysis of diversity networks. Organization Studies, 1-22.

Dinesen PT, Hooghe M (2010) When in Rome, do as the Romans do: The acculturation of generalized trust among immigrants in Western Europe. International Migration Review 44(3): 697-727.

Fleischmann F, Phalet K, and Klein O (2011) Religious identification and politicization in the face of discrimination: Support for political Islam and political action among the Turkish and Moroccan second generation in Europe. British Journal of Social Psychology 50(4): 628-648.

Giuliani C, Tagliabue S, and Regalia C (2018) Psychological well-being, multiple identities, and discrimination among first and second generation immigrant Muslims. Europe's Journal of Psychology, 14(1): 66-87.

Gong F, Xu J, Fujishiro K, and Takeuchi DT (2011) A life course perspective on migration and mental health among Asian immigrants: The role of human agency. Social Science and Medicine 73(11): 1618-1626.

Hayibor S (2017) Is fair treatment enough? Augmenting the fairness-based perspective on stakeholder behaviour. Journal of Business Ethics 140(1): 43-64.

INSEE (2016a) France, Portrait Social. Available at:

https://www.insee.fr/fr/statistiques/2492313

INSEE (2016b) Immigrés et descendants d'immigrés. Available at: https://www.insee.fr/fr/statistiques/fichier/../FPORSOC16j3_F2.3_immigres.pdf 
Janssens M, Zanoni P (2014) Alternative diversity management: Organizational practices fostering ethnic equality at work. Scandinavian Journal of Management 30(3): 317331.

Kaduvettoor-Davidson A, Inman AG (2013) South Asian Americans: Perceived discrimination, stress, and well-being. Asian American Journal of Psychology 4(3): $155-165$.

Kalev A, Dobbin F, and Kelly E (2006) Best practices or best guesses? Assessing the efficacy of corporate affirmative action and diversity policies. American Sociological Review, 71(4): 589-617.

Kirton G, Greene AM (2015) The Dynamics of Managing Diversity: A Critical Approach. London: Routledge.

Klarsfeld A, Ng E, and Tatli A (2012) Social regulation and diversity management: A comparative study of France, Canada and the UK. European Journal of Industrial Relations 18(4): 309-327.

Kossek EE, Pichler S (2006) EEO and the management of diversity. In: Boxell P, Purcell J, and Wright PM (eds) Handbook of Human Resource Management. Oxford: Oxford University Press, 251-272.

Lacroix T (2015) The long, troubled history of assimilation in France. The Conversation. Available at: https://theconversation.com/the-long-troubled-history-of-assimilation-infrance-51530

Leary, MR, Tangney JP (2005) Handbook of Self and Identity. NewYork: Guilford.

Liu CM, Suyemoto KL (2016) The effects of racism-related stress on Asian Americans: Anxiety and depression among different generational statuses. Asian American Journal of Psychology 7(2): 137-146. 
MacKenzie R, Forde C (2009) The rhetoric of the 'good worker' versus the realities of employers' use and the experiences of migrant workers. Work, Employment and Society 23(1): 142-159.

Major B, Gramzow R, McCoy S, Levin S, Schmader T, and Sidanius J (2002) Attributions to discrimination: The role of group status and legitimizing ideology. Journal of Personality and Social Psychology 82(3): 269-282.

Midtbøen AH (2016) Discrimination of the second generation: Evidence from a field experiment in Norway. Journal of International Migration and Integration 17(1): $253-272$.

Moorman R (1991) Relationship between organizational justice and organizational citizenship behaviors: Do fairness perceptions influence employee citizenship? Journal of Applied Psychology 76(6): 845-855.

Nishii LH (2013) The benefits of climate for inclusion for gender-diverse groups. Academy of Management Journal 56(6): 1754-1774.

Nkomo S, Hoobler JM (2014) A historical perspective on diversity ideologies in the United States: Reflections on human resource management research and practice. Human Resource Management Review 24(3): 245-257.

Olsen JE, Martins LL (2012) Understanding organizational diversity management programs: A theoretical framework and directions for future research. Journal of Organizational Behavior 33(8): 1168-1187.

Organisation for Economic Co-operation and Development (2013) Principaux résultats de l'Enquête PISA 2012. Paris: OECD.

Rot G (2006) Sociologie de l'atelier: Renault, le travail ouvrier et le sociologue. Paris: Octarès.

Sabatier C (2008) Ethnic and national identity among second-generation immigrant 
adolescents in France: The role of social context and family. Journal of Adolescence 31(2): 185-205.

Schneider J (2016) First/Second Generation Immigrants. NESET II ad hoc question No. 4/2016. Institute for Migration Research and Intercultural Studies (IMIS). Osnanbrück: University of Osnabrück.

Schwab A, Werbel JD, Hofmann H, and Henriques PL (2016) Managerial gender diversity and firm performance: An integration of different theoretical perspectives. Group and Organization Management 41(1): 5-31.

Sellers RM, Shelton JN (2003) The role of racial identity in perceived racial discrimination. Journal of Personality and Social Psychology 84(5): 1079-1092.

Settles IH, Buchanan NT, and Dotson K (2018) Scrutinized but not recognized: (In)visibility and hypervisibility experiences of faculty of color. Journal of Vocational Behavior. 10.1016/j.jvb.2018.06.003

Shinnar RS (2008) Coping with negative social identity: The case of Mexican immigrants. Journal of Social Psychology 148(5): 553-576.

Shore LM, Randel AE, Chung BG, Dean MA, Ehrhart KH, and Singh G (2011) Inclusion and diversity in work groups: A review and model for future research. Journal of Management 37(4): 1262-1289.

Sweeney PD, McFarlin DB (1997) Process and outcome: Gender differences in the assessment of justice. Journal of Organizational Behavior 18(1): 83-98.

Van Knippenberg D, De Dreu CK, and Homan AC (2004) Work group diversity and group performance: An integrative model and research agenda. Journal of Applied Psychology 89(6): 1008-1022.

Van Laer K, Janssens M (2011) Ethnic minority professionals' experiences with subtle discrimination in the workplace. Human Relations 64(9): 1203-1227. 
Van Laer K, Janssens M (2014) Between the devil and the deep blue sea: Exploring the hybrid identity narratives of ethnic minority professionals. Scandinavian Journal of Management 30(2): 186-196.

Van Laer K, Janssens M (2016) Agency of ethnic minority employees: Struggles around identity, career and social change. Organization 24(2): 198-217.

Watson T (2009) Narrative, life story and manager identity. Human Relations 63(3): 425-452.

Whisenant W, Lee DL, and Dees W (2015) Role congruity theory: Perceptions of fairness and sexism in sport management. Public Organization Review 15(4): 475-485.

Wiley S, Deaux K, and Hagelskamp C (2012) Born in the USA: How immigrant generation shapes meritocracy and its relation to ethnic identity and collective action. Cultural Diversity and Ethnic Minority Psychology 18(2): 171-180.

Wingfield AH, Wingfield JH (2014) When visibility hurts and helps: How intersections of race and gender shape Black professional men's experiences with tokenization. Cultural Diversity and Ethnic Minority Psychology 20(4): 483-490.

Yang Y, Konrad AM (2011) Understanding diversity management practices: Implications of institutional theory and resource-based theory. Group and Organization Management 36(1): 6-38.

Ybema S, Keenoy T, Oswick C, Beverungen A, Ellis N, and Sabelis I (2009) Articulating identities. Human Relations 63(3): 299-322.

Zanoni P (2011) Diversity in the lean automobile factory: Doing class through gender, disability and age. Organization 18(1): 105-127.

Zanoni P, Janssens M, Benschop Y, and Nkomo SM (2010) Unpacking diversity, grasping inequality: Rethinking difference through critical perspectives. Organization 17(1): 929. 
Table 1: Demographic characteristics of the sample

\section{First generation}

\begin{tabular}{|l|l|l|l|l|}
\hline Interviewee & Function & Gender & Age & Ethnic origin \\
\hline 1 & Production worker & Male & 46 & Cambodian \\
\hline 2 & Production worker & Male & 32 & Chinese \\
\hline 4 & Technician & Male & 48 & Tunisian \\
\hline 7 & Assembly worker & Male & 35 & Senegalese \\
\hline 8 & Production & Female & 50 & Turkish \\
\hline 9 & Forklift driver & Male & 42 & Serbian \\
\hline 12 & HR worker & Male & 48 & Portuguese \\
\hline 13 & Responsible for security & Male & 51 & Moroccan \\
\hline 14 & Group HR director & Male & 45 & German \\
\hline
\end{tabular}

\section{Second generation}

\begin{tabular}{|l|l|l|l|l|}
\hline Interviewee & Function & Gender & Age & Ethnic origin \\
\hline 3 & HR assistant & Female & 44 & Moroccan \\
\hline 5 & HR assistant & Female & 40 & Algerian \\
\hline 6 & Quality analyst & Female & 35 & Serbian \\
\hline 10 & Maintenance worker & Male & 56 & Martinican \\
\hline 11 & Production team leader & Male & 39 & Algerian \\
\hline 15 & Production worker & Male & 42 & Portuguese \\
\hline 16 & Production worker & Male & 56 & Burkinabé \\
\hline
\end{tabular}


Figure 2: Conceptual model of perceptions of diversity management practices among migrant workers

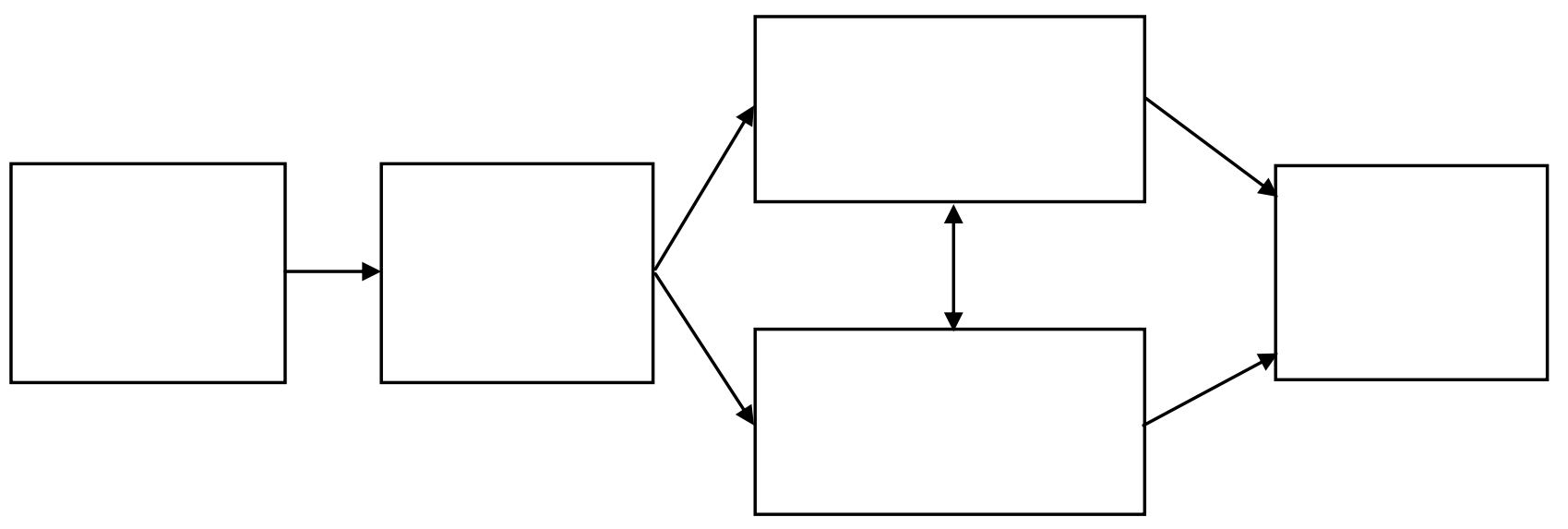


Figure 1: Data analysis structure

First-order themes

Second-order themes Aggregate dimensions

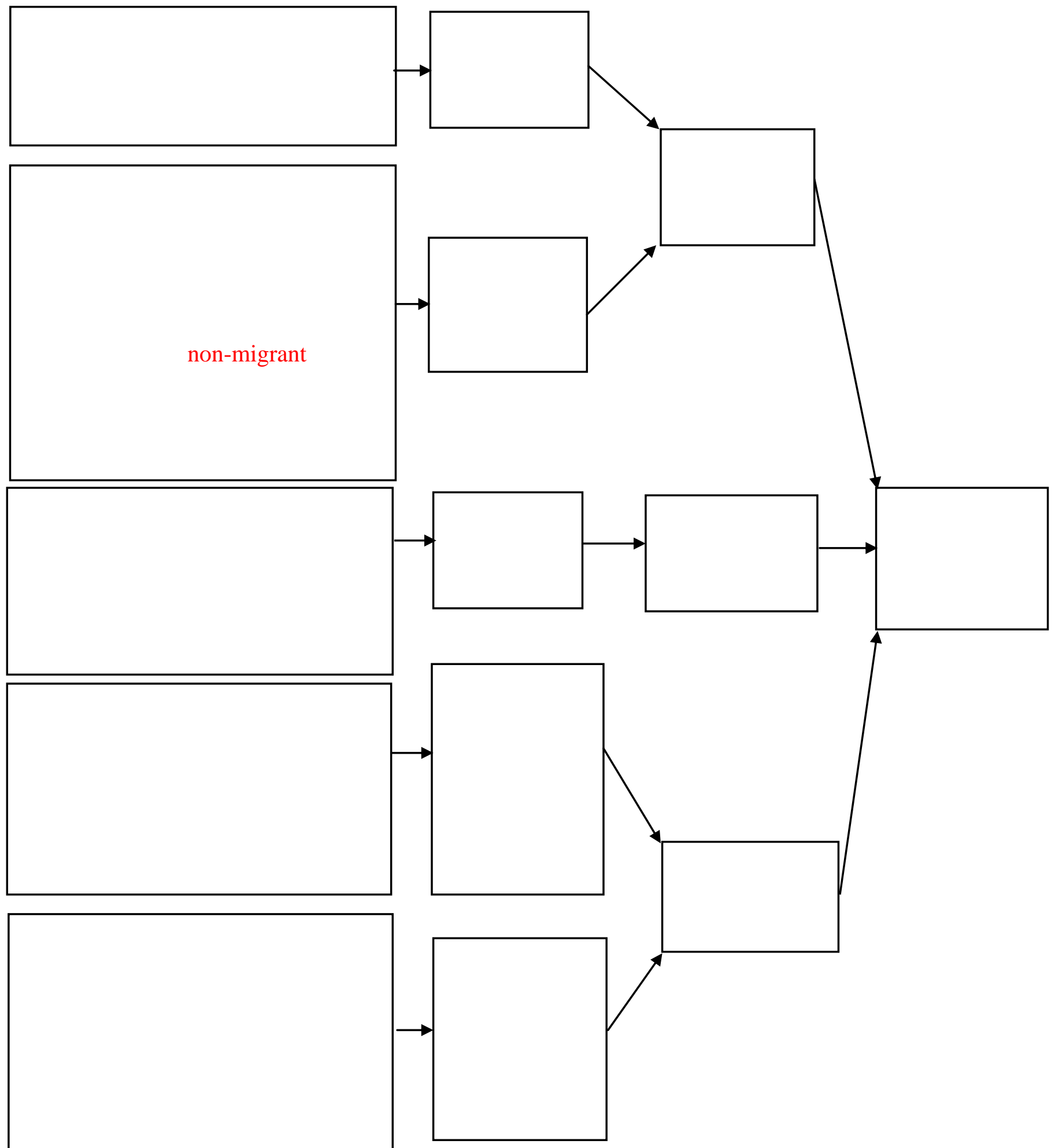

